\title{
PREDIKSI PERMINTAAN PRODUK MIE INSTAN DENGAN METODE FUZZY TAKAGI-SUGENO
}

\author{
Ahmad Bahroini ${ }^{1}$, Andi Farmadi ${ }^{2}$, Radityo Adi Nugroho ${ }^{3}$ \\ 1,2,3Prodi Ilmu Komputer FMIPA UNLAM \\ Jl. A. Yani Km 36 Banjarbaru, Kalimantan selatan \\ Email : abahroini8@gmail.com
}

\begin{abstract}
In the A minimarket, instant noodles are sold to consumers is not constant every day. So often a mismatch minimarket in buying noodles. For that, Fuzzy logic which can be used for prediction of purchase. In this study using Fuzzy TakagiSugeno inference system, this Fuzzy set used 3 membership function, which isdescended, ascend, and triangles. The process of determining theprediction results is used assertion (defuzzy) by using the concept of weighted averaged. The results can be concluded that the method of Fuzzy Takagi-Sugeno inference can predict the purchase of instant noodles
\end{abstract}

Keywords : Fuzzy logic, Takagi Sugeno, Prediction the purchase, Instant noodles

\begin{abstract}
Abstrak
Pada minimarket A, mie instan merupakan produkyang paling banyak terjual. Tetapi jumlah mie instan yang terjual ke konsumen setiap harinya tidak konstan, sehingga sering terjadi ketidaksesuaian minimarket dalam membeli mie. Untuk itu, digunakan logika fuzzy untuk prediksi pembeliannya. Pada penelitian ini menggunakan Sistem Inferensi Fuzzy Takagi Sugeno, himpunan fuzzy yang digunakan menggunakan 3 fungsi keanggotaan, yaitu turun, naik, dan segitiga. Proses penentuan hasil prediksi digunakan penegasan (defuzzy) dengan menggunakan konsep rata-rata tertimbang (weighted average). Hasil yang didapat, metode fuzzy inferensi TakagiSugeno dapat memprediksi pembelian mie instan dengan nilai error 35,55\%.
\end{abstract}

Kata kunci : Logika fuzzy, Takagi Sugeno, Prediksi pembelian, Mie instan

\section{PENDAHULUAN}

Tahun 2014 Asosiasi Mie Instan Dunia yang berbasis di Osaka, Jepang melaporkan, Indonesia menyumbang konsumsi mie sebanyak 14,9 miliar bungkus/tahun terbanyak kedua di Dunia. Berarti orang Indonesia mengkonsumsi rata-rata 58 bungkus mie instant per tahun . Begitu juga terjadi pada minimarket $\mathrm{A}$, mie instan merupakan produk yang paling banyak terjual di minimarket tersebut. Jumlah mie instan yang terjual ke konsumen setiap harinya tidak konstan, sehingga sering terjadi ketidaksesuaian minimarket dalam membeli mie dari suplier, yang mengakibatkan sisa stok bisa terjadi kekurangan atau kelebihan 
Selama ini di minimarket A belum ada sistem yang dapat memprediksi jumlah mie instan yang akan dibeli dari suplier, Oleh karena itu diperlukan sebuah cara agar mampu memprediksi pemintaan barang tersebut. Penulis menggunakan logika fuzzy dalam prediksinya. Menurut Yudanto dkk logika fuzzy memiliki toleransi pada data yang ada ${ }^{[1]}$. Logika fuzzy nilai keanggotaan berada diantara 0 dan 1. Artinya, bisa saja suatu keadaan mempunyai dua nilai "Ya dan Tidak", "Benar dan Salah", "Baik dan Buruk" secara bersamaan, namun besar nilainya tergantung pada bobot keanggotaan yang dimilikinya [4]. Dalam logika fuzzy terdapat Sistem Inferensi Fuzzy yang dapat digunakan untuk memprediksi.

Sistem Inferensi Fuzzy adalah sistem yang dapat melakukan penalaran dengan prinsip serupa seperti manusia melakukan penalaran dengan nalurinya. Terdapat beberapa jenis FIS yang dikenal yaitu Mamdani, Takagi-Sugeno dan Tsukamoto. Fuzzy metode Takagi-Sugeno merupakan metode inferensi fuzzy untuk aturan yang direpresentasikan dalam bentuk IF - THEN, dimana output (konsekuen) sistem tidak berupa himpunan fuzzy, melainkan berupa konstanta atau persamaan linear [2]. Oleh karena itu, penelitian ini mencoba untuk menggunakan metode fuzzy inference Takagi-Sugeno untuk memprediksi pembelian mie instan.

\section{METODE PENELITIAN}

ahapan-tahapan dalam metode Fuzzy Takagi-Sugeno yang digunakan yaitu sebagai berikut:

a. Langkah pertama, Pembentukan himpunan Fuzzy. Pada tahapan ini variabel input dari sistem fuzzy dibuat ke dalam himpunan fuzzy untuk dapat digunakan dalam perhitungan. Pada tahap ini menentukan derajat keanggotaan dari setiap himpunan fuzzy. Himpunan fuzzy yang digunakan dalam penelitian ini menggunakan 3 fungsi keanggotaan, yaitu :

1) Fungsi linear turun (bahu kiri) dirumuskan sebagai berikut

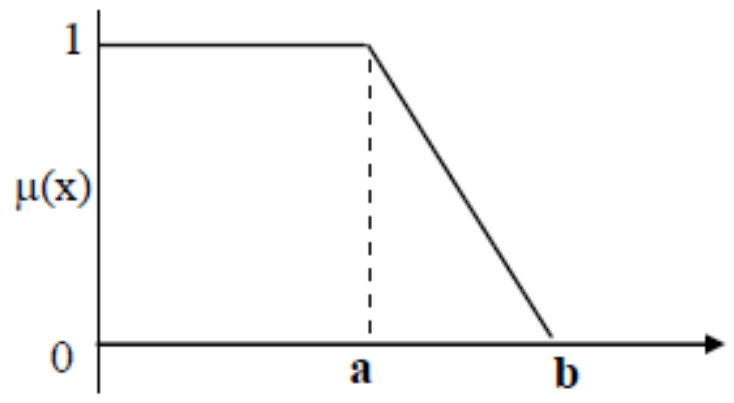

\section{Domain (x)}

Gambar 1 Fungsi Linear Turun

Sumber : Aplikasi Logika Fuzzy untuk Pendukung Keputusan, 2010

$$
\mu(x)= \begin{cases}1 ; & x \leq a \\ (b-x) /(b-a) ; & a \leq x \leq b \\ 0 ; & x \geq b\end{cases}
$$


2) Fungsi linear naik (bahu kanan) dirumuskan sebagai berikut

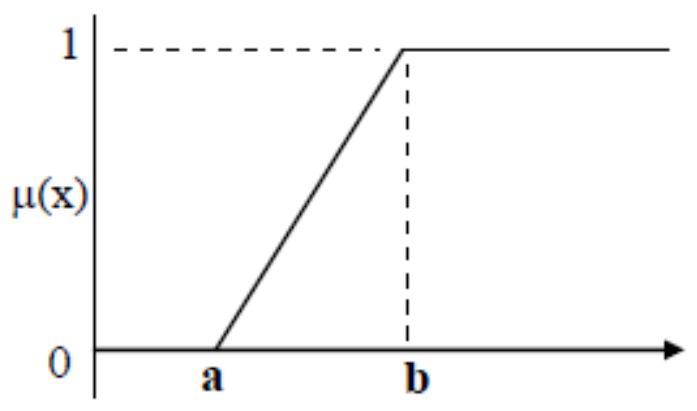

Gambar 2 Fungsi Linear Naik

\section{Domain $(\mathrm{x})$}

Sumber : Aplikasi Logika Fuzzy untuk Pendukung Keputusan, 2010

$$
\mu(\mathrm{x})= \begin{cases}0 ; & \mathrm{x} \leq \mathrm{a} \\ (\mathrm{x}-\mathrm{a}) /(\mathrm{b}-\mathrm{a}) ; & \mathrm{a} \leq \mathrm{x} \leq \mathrm{b} \\ 1 ; & \mathrm{x} \geq \mathrm{b}\end{cases}
$$

3) Fungsi segitiga dirumuskan sebagai berikut

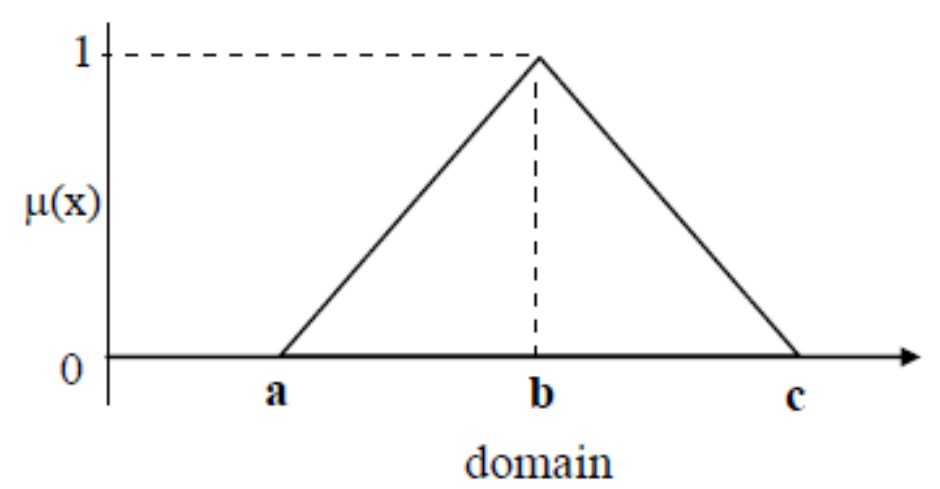

Gambar 3 Fungsi Linear Segitiga

Sumber : Aplikasi Logika Fuzzy untuk Pendukung Keputusan, 2010

$$
\mu(\mathrm{x})= \begin{cases}0 ; & \mathrm{x} \leq \mathrm{a} \text { atau } \mathrm{x} \geq \mathrm{c} \\ (\mathrm{x}-\mathrm{a}) /(\mathrm{b}-\mathrm{a}) ; & \mathrm{a} \leq \mathrm{x} \leq \mathrm{b} \\ (\mathrm{b}-\mathrm{x}) /(\mathrm{c}-\mathrm{b}) ; & \mathrm{b} \leq \mathrm{x} \leq \mathrm{c}\end{cases}
$$

b. Langkah kedua, membentuk fungsi implikasi. Bentuk umum dari aturan yang digunakan dalam fungsi implikasi adalah sebagai berikut:

IF $x$ is $A$ THEN $y$ is $B$

$$
\text { dan }
$$


$\operatorname{IF}\left(\mathrm{x}_{1}\right.$ is $\left.\mathrm{A}_{1}\right)$ AND ( $\mathrm{x}_{2}$ is $\left.\mathrm{A}_{2}\right)$ AND ... AND ( $\mathrm{x}_{\mathrm{N}}$ is $\left.\mathrm{A}_{\mathrm{N}}\right)$ THEN y is $\mathrm{B}$

c. Langkah terakhir, defuzzifikasi. Proses penetapan hasil akhir dari sistem fuzzy

$$
\mathrm{WA}=\frac{\underline{\alpha_{1}} \underline{Z}_{1}+\underline{\alpha}_{\underline{2}} \underline{Z_{2}}+\alpha_{\underline{3}} \underline{Z}_{3}+\ldots+\alpha_{\underline{n}} \underline{Z}_{n}}{\alpha_{1}+\alpha_{2}+\alpha_{3}+\ldots+\alpha_{n}}
$$

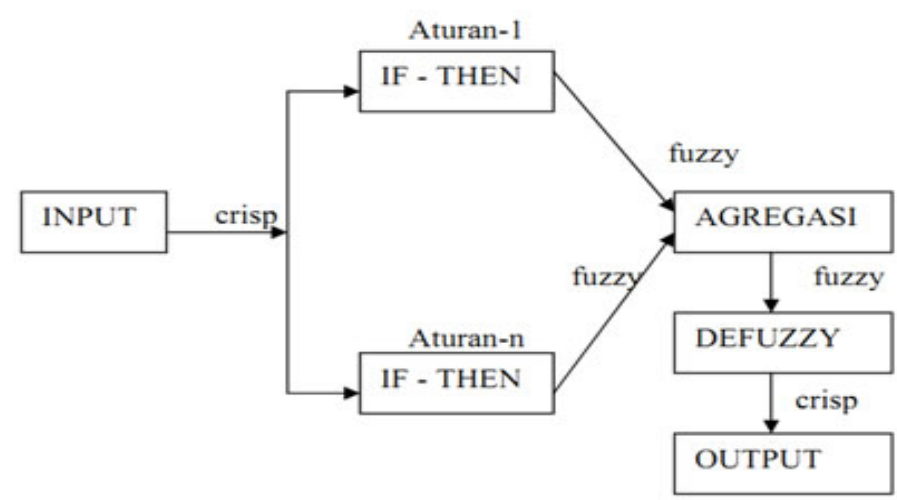

Gambar 4 Sistem Inferensi Fuzzy

\section{HASIL DAN PEMBAHASAN}

Dalam penelitian ini mengambil data mie instan $X$, karena pada minimarket $A$ mie instan yang paling banyak diminati konsumen. Data yang dikumpulkan meliputi data penjualan, data sisa stok, dan data pembelian dari bulan Juni 2014 hingga Desember 2014.

Tabel 1 Data Transaksi Mie instan X

\begin{tabular}{lclllll}
\hline $\begin{array}{c}\text { Minggu } \\
\text { ke }\end{array}$ & Tanggal & Penjualan & Sisa stok & Pembelian & Ket \\
\hline 1 & $01 / 06 / 2014$ & 229 & 47 & 200 & \\
2 & $08 / 06 / 2014$ & 273 & 18 & 600 & \\
3 & $15 / 06 / 2014$ & 256 & 345 & 200 & \\
4 & $22 / 06 / 2014$ & 303 & 289 & 400 & \\
5 & $29 / 06 / 2014$ & 354 & 386 & 200 & \\
6 & $06 / 07 / 2014$ & 363 & 232 & 200 & \\
7 & $13 / 07 / 2014$ & 181 & 69 & 600 & \\
8 & $20 / 07 / 2014$ & 590 & 488 & 600 & Data \\
9 & $27 / 07 / 2014$ & 238 & 498 & 200 & Training \\
10 & $03 / 08 / 2014$ & 267 & 460 & 200 & \\
11 & $10 / 08 / 2014$ & 207 & 393 & 100 & \\
12 & $17 / 08 / 2014$ & 314 & 286 & 100 & \\
13 & $24 / 08 / 2014$ & 272 & 72 & 250 & \\
14 & $31 / 08 / 2014$ & 195 & 50 & 200 & \\
15 & $07 / 09 / 2014$ & 140 & 55 & 150 & \\
16 & $14 / 09 / 2014$ & 131 & 65 & 118 & \\
& & & & & \\
& & & & &
\end{tabular}




\begin{tabular}{lcllll}
\hline $\begin{array}{c}\text { Minggu } \\
\text { ke }\end{array}$ & Tanggal & Penjualan & Sisa stok & Pembelian & Ket \\
\hline 17 & $21 / 09 / 2014$ & 148 & 52 & 130 \\
18 & $28 / 09 / 2014$ & 392 & 34 & 400 \\
19 & $05 / 10 / 2014$ & 382 & 42 & 550 & \\
20 & $12 / 10 / 2014$ & 241 & 210 & 500 \\
21 & $19 / 10 / 2014$ & 202 & 469 & 250 \\
22 & $26 / 10 / 2014$ & 206 & 517 & 150 & \\
23 & $02 / 11 / 2014$ & 304 & 461 & 100 \\
24 & $09 / 11 / 2014$ & 201 & 257 & 200 & \\
25 & $16 / 11 / 2014$ & 185 & 256 & 100 & Data Uji \\
26 & $23 / 11 / 2014$ & 153 & 171 & 150 \\
27 & $30 / 11 / 2014$ & 195 & 168 & 150 \\
28 & $07 / 12 / 2014$ & 107 & 123 & 200 & \\
29 & $14 / 12 / 2014$ & 113 & 216 & 200 & \\
30 & $21 / 12 / 2014$ & 199 & 303 & 100 & \\
\hline
\end{tabular}

Sumber : Penerapan Metode Fuzzy Takagi-Sugeno untuk prediksi Permintaan Barang Produk Mie Instan di Minimarket A. 2015

Berdasarkan data tersebut, maka data dibagi menjadi 2 bagian yaitu data training dan data uji. Data training dari minggu pertama sampai minggu ke 20 sebagai pembentuk himpunan fuzzy dan data uji dari minggu ke 21 sampai minggu ke 30 sebagai data perbandingan prediksi.

Proses pertama dalam fuzzy Takagi-Sugeno ialah pembentukan himpunan fuzzy dari data training, didapatkan himpunan fuzzy sebagai berikut :

Tabel 2 Himpunan Fuzzy Penjualan

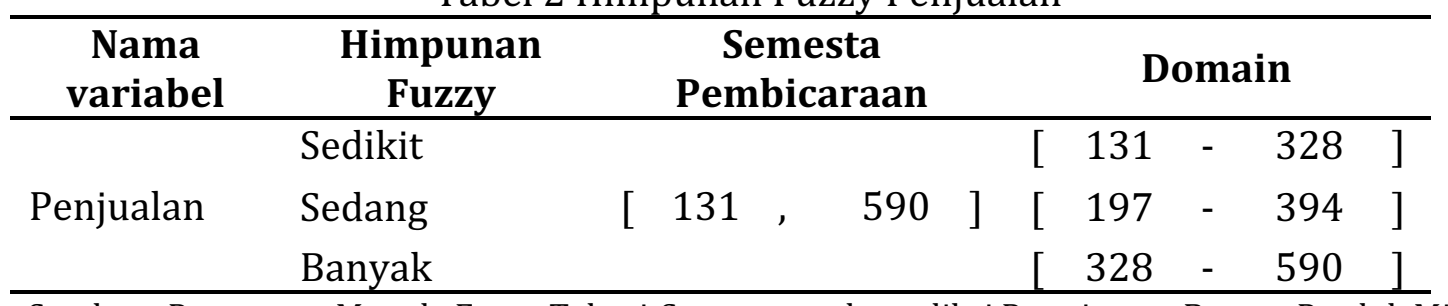

Sumber : Penerapan Metode Fuzzy Takagi-Sugeno untuk prediksi Permintaan Barang Produk Mie Instan di Minimarket A. 2015

Tabel 3 Himpunan Fuzzy Sisa Stok

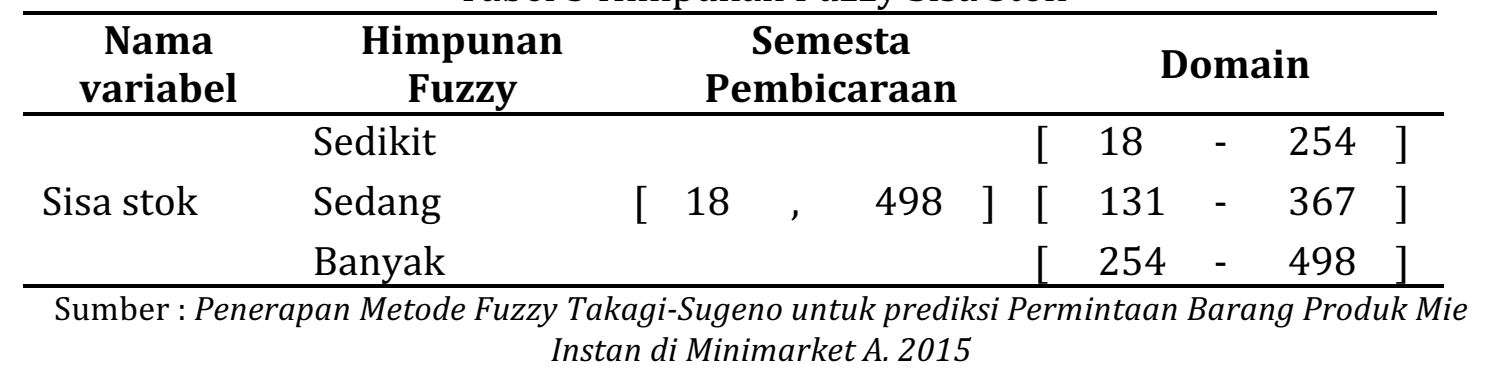


Tabel 4 Himpunan Fuzzy Pembelian

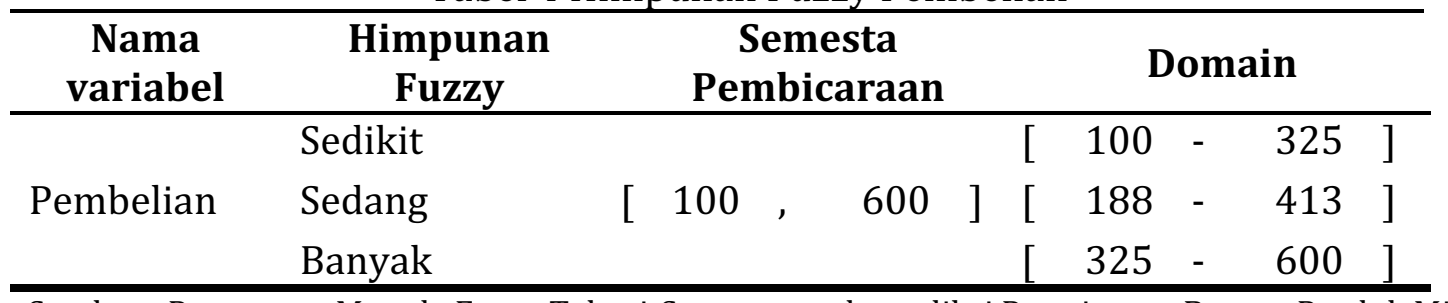

Sumber : Penerapan Metode Fuzzy Takagi-Sugeno untuk prediksi Permintaan Barang Produk Mie Instan di Minimarket A. 2015

Data mie instan $X$ yang ada pada tabel diambil data ke 30, jumlah penjualan ( $\mathrm{x}$ ) ialah 199 dan jumlah sisa stok (y) ialah 303, maka didapatkan derajat keanggotaannya adalah :

a. Derajat Keanggotaan Penjualan

$$
\begin{aligned}
& \begin{array}{l}
\text { Turun } \\
(\text { Sedikit })
\end{array} \mu(\mathrm{x})=\frac{(\mathrm{b}-\mathrm{x})}{(\mathrm{b}-\mathrm{a})}=\frac{328-199}{328-197}=\frac{129}{131}=0,985=0,982 \\
& \begin{array}{l}
\text { Naik } \\
\text { (Banyak) }
\end{array}(\mathrm{x})=\frac{(\mathrm{x}-\mathrm{b})}{(\mathrm{c}-\mathrm{b})}=\frac{199-328}{393-328}=\frac{-129}{66}=-1,955=0
\end{aligned}
$$

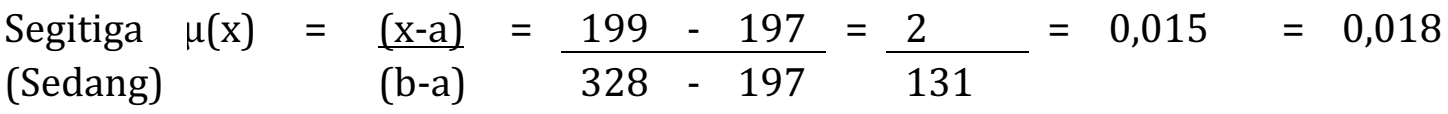

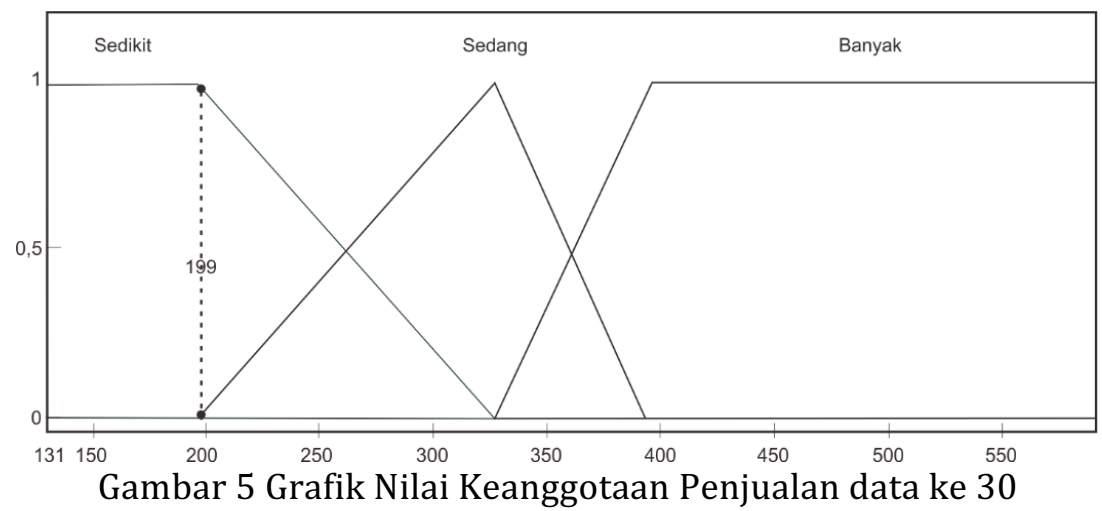

Sumber : Penerapan Metode Fuzzy Takagi-Sugeno untuk prediksi Permintaan Barang Produk Mie Instan di Minimarket A. 2015

b. Derajat Keanggotaan Sisa Stok

$$
\begin{aligned}
& \begin{array}{l}
\text { Turun } \\
\text { Sedikit }
\end{array}
\end{aligned}
$$

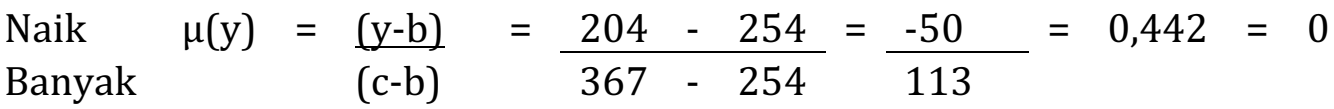

$$
\begin{aligned}
& \begin{array}{l}
\text { Segitiga } \mu(y)=\frac{(y-a)}{(b-a)}=\frac{204-131}{254-131}=\frac{73}{123}=0,593=0,595 \\
\text { Sedang }
\end{array}
\end{aligned}
$$




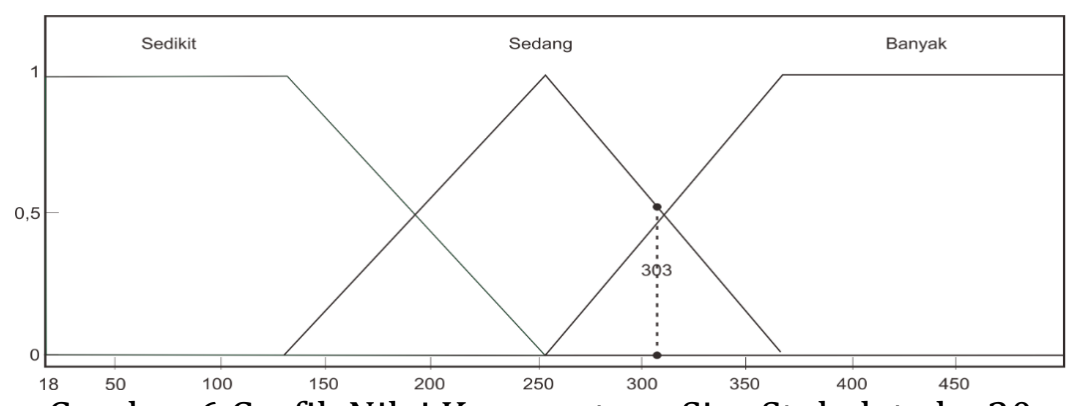

Gambar 6 Grafik Nilai Keanggotaan Sisa Stok data ke 30

Sumber : Penerapan Metode Fuzzy Takagi-Sugeno untuk prediksi Permintaan Barang Produk Mie Instan di Minimarket A. 2015

Langkah kedua, membentuk fungsi implikasi dari data training mie instan X. Didapatkan fungsi implikasi sebagai berikut :

Tabel 5 Fungsi Implikasi Mie instan X

\begin{tabular}{|c|c|c|c|c|c|c|c|c|c|}
\hline RULE & & [N] & $\mathbf{N}$ & $\begin{array}{c}\text { SISA } \\
\text { STOK } \\
\text { (Y) }\end{array}$ & & \multicolumn{4}{|c|}{ PEMBELIAN (Z) } \\
\hline $\mathrm{R} 1$ & IF & sedikit & AND & sedikit & THEN & 1,311 & 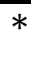 & dalan & stok \\
\hline $\mathrm{R} 2$ & IF & sedikit & AND & sedikit & THEN & 1,233 & & enjualan & - stok \\
\hline R3 & IF & sedikit & AND & sedikit & THEN & 2,969 & * & penjualan & - stok \\
\hline $\mathrm{R} 4$ & IF & sedikit & AND & sedang & THEN & 1,679 & & penjualan & - stok \\
\hline R5 & IF & sedikit & AND & sedang & THEN & 2,201 & 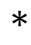 & penjualan & - stok \\
\hline R6 & IF & sedikit & AND & sedang & THEN & 2,129 & * & penjualan & - stok \\
\hline R7 & IF & sedikit & AND & banyak & THEN & 2,229 & 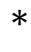 & penjualan & stok \\
\hline R8 & IF & sedikit & AND & banyak & THEN & 2,452 & P & penjualan & - stok \\
\hline R9 & IF & sedikit & AND & banyak & THEN & 0,758 & * & penjualan & - stok \\
\hline R10 & IF & sedang & AND & sedikit & THEN & 1,187 & 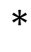 & penjualan & - Stok \\
\hline R11 & IF & sedang & AND & sedikit & THEN & 1,160 & T & penjualan & - Stok \\
\hline $\mathrm{R} 12$ & IF & sedang & AND & sedikit & THEN & 1,967 & $*$ & penjualan & - stok \\
\hline $\mathrm{R} 13$ & IF & sedang & AND & sedang & THEN & 1,516 & & penjualan & - stok \\
\hline R14 & IF & sedang & AND & sedang & THEN & 1,864 & * & penjualan & - stok \\
\hline R15 & IF & sedang & AND & sedang & THEN & 2,610 & * & penjualan & - stok \\
\hline R16 & IF & sedang & AND & banyak & THEN & 1,423 & & penjualan & - stok \\
\hline R17 & IF & sedang & AND & banyak & THEN & 2,293 & $*$ & penjualan & - stok \\
\hline R18 & IF & sedang & AND & banyak & THEN & 2,274 & A & penjualan & - stok \\
\hline R19 & IF & banyak & AND & sedikit & THEN & 1,190 & & penjualan & stok \\
\hline R20 & IF & banyak & AND & sedikit & THEN & 1,149 & $\uparrow$ & penjualan & - stok \\
\hline R21 & IF & banyak & AND & sedikit & THEN & 1,328 & $\uparrow$ & penjualan & - stok \\
\hline R22 & IF & banyak & AND & sedang & THEN & 1,190 & & penjualan & stok \\
\hline R23 & IF & banyak & AND & sedang & THEN & 1,190 & & penjualan & - stok \\
\hline R24 & IF & banyak & AND & sedang & THEN & 0 & & penjualan & - stok \\
\hline R25 & IF & banyak & AND & banyak & THEN & 1,655 & & penjualan & - stok \\
\hline R26 & IF & banyak & AND & banyak & THEN & 1,655 & $\uparrow$ & penjualan & - stok \\
\hline R27 & IF & banyak & AND & banyak & THEN & 1,844 & t & penjualan & - $\quad$ stok \\
\hline
\end{tabular}

Sumber : Penerapan Metode Fuzzy Takagi-Sugeno untuk prediksi Permintaan Barang Produk Mie Instan di Minimarket A. 2015 
Dari fungsi implikasi tersebut didapat hasil dari masing-masing rule sebagai berikut:

Tabel 6 Hasil Fungsi Implikasi

\begin{tabular}{|c|c|}
\hline RULE & $\mathbf{Z}$ \\
\hline R1 & $-42,038$ \\
\hline R2 & $-57,645$ \\
\hline R3 & 287,760 \\
\hline R4 & 31,141 \\
\hline R5 & 135,082 \\
\hline R6 & 120,652 \\
\hline R7 & 140,552 \\
\hline R8 & 184,924 \\
\hline R9 & $-152,163$ \\
\hline R10 & $-66,796$ \\
\hline R11 & $-72,090$ \\
\hline R12 & 88,367 \\
\hline R13 & $-1,297$ \\
\hline R14 & 67,997 \\
\hline R15 & 216,389 \\
\hline R16 & $-19,878$ \\
\hline R17 & 153,223 \\
\hline R18 & 149,512 \\
\hline R19 & $-66,174$ \\
\hline R20 & $-74,426$ \\
\hline R21 & $-38,640$ \\
\hline $\mathrm{R} 22$ & $-66,174$ \\
\hline R23 & $-66,174$ \\
\hline $\mathrm{R} 24$ & 0 \\
\hline R25 & 26,418 \\
\hline R26 & 26,418 \\
\hline $\mathrm{R} 27$ & 63,969 \\
\hline
\end{tabular}

Sumber : Penerapan Metode Fuzzy Takagi-Sugeno untuk prediksi Permintaan Barang Produk Mie Instan di Minimarket A. 2015

Proses terakhir yaitu defuzifikasi atau proses penentuan hasil dari metode fuzyy Takagi-Sugeno. Hasil proses fungsi implikasi yang ada dikalikan dengan $\alpha$ predikat (rumus : $\min (\mu(\mathrm{x}) \Lambda \mu(\mathrm{y}))$ yang didapat dari nilai keanggotaan. Sehingga $\alpha$ predikat dan Z x $\alpha$-predikat dari masing-masing aturan fuzzy adalah sebagai berikut: Tabel 7 Nilai $\alpha$-predikat

\begin{tabular}{llllllll}
\hline \multicolumn{2}{c}{ RULE } & $\boldsymbol{\mu}(\mathbf{x})$ & $\boldsymbol{\Lambda}$ & $\boldsymbol{\mu}(\mathbf{y})$ & $\boldsymbol{\alpha}$-predikat & $\mathbf{Z} \mathbf{x} \boldsymbol{\alpha}$-predikat \\
\hline[ & $\mathrm{R} 1$ & ] & 0,9847 & $\Lambda$ & 0 & 0 & 0 \\
{[} & $\mathrm{R} 2$ & ] & 0,9847 & $\Lambda$ & 0 & 0 & 0 \\
{[} & $\mathrm{R} 3$ & ] & 0,9847 & $\Lambda$ & 0 & 0 & 0 \\
{[} & $\mathrm{R} 4$ & ] & 0,9847 & $\Lambda$ & 1 & 0,984732824 & 30,66601638 \\
{[} & $\mathrm{R} 5$ & ] & 0,9847 & $\Lambda$ & 1 & 0,984732824 & 133,0196276 \\
{[} & $\mathrm{R} 6$ & ] & 0,9847 & $\Lambda$ & 1 & 0,984732824 & 118,8103232
\end{tabular}




\begin{tabular}{|c|c|c|c|c|c|c|c|}
\hline & RULE & & $\mu(x)$ & $\Lambda$ & $\mu(y)$ & $\alpha$-predikat & $\mathrm{Z} \times \alpha$-predikat \\
\hline [ & R7 & ] & 0,9847 & $\Lambda$ & 0,434 & 0,433628319 & 60,94747816 \\
\hline [ & R8 & ] & 0,9847 & $\Lambda$ & 0,434 & 0,433628319 & 80,18826758 \\
\hline [ & R9 & ] & 0,9847 & $\Lambda$ & 0,434 & 0,433628319 & $-65,98210618$ \\
\hline [ & $\mathrm{R} 10$ & ] & 0,0153 & $\Lambda$ & 0 & 0 & 0 \\
\hline [ & $\mathrm{R} 11$ & ] & 0,0153 & $\Lambda$ & 0 & 0 & 0 \\
\hline [ & $\mathrm{R} 12$ & ] & 0,0153 & $\Lambda$ & 0 & 0 & 0 \\
\hline [ & $\mathrm{R} 13$ & ] & 0,0153 & $\Lambda$ & 1 & 0,015267176 & $-0,019799678$ \\
\hline [ & $\mathrm{R} 14$ & ] & 0,0153 & $\Lambda$ & 1 & 0,015267176 & 1,038118785 \\
\hline [ & $\mathrm{R} 15$ & ] & 0,0153 & $\Lambda$ & 1 & 0,015267176 & 3,303642071 \\
\hline [ & $\mathrm{R} 16$ & ] & 0,0153 & $\Lambda$ & 0,434 & 0,015267176 & $-0,303476906$ \\
\hline[ & $\mathrm{R} 17$ & ] & 0,0153 & $\Lambda$ & 0,434 & 0,015267176 & 2,339279191 \\
\hline [ & $\mathrm{R} 18$ & ] & 0,0153 & $\Lambda$ & 0,434 & 0,015267176 & 2,282619102 \\
\hline [ & $\mathrm{R} 19$ & ] & 0 & $\Lambda$ & 0 & 0 & 0 \\
\hline [ & $\mathrm{R} 20$ & ] & 0 & $\Lambda$ & 0 & 0 & 0 \\
\hline[ & $\mathrm{R} 21$ & ] & 0 & $\Lambda$ & 0 & 0 & 0 \\
\hline [ & $\mathrm{R} 22$ & ] & 0 & $\Lambda$ & 1 & 0 & 0 \\
\hline [ & $\mathrm{R} 23$ & ] & 0 & $\Lambda$ & 1 & 0 & 0 \\
\hline [ & R24 & ] & 0 & $\Lambda$ & 1 & 0 & 0 \\
\hline [ & R25 & ] & 0 & $\Lambda$ & 0,434 & 0 & 0 \\
\hline [ & R26 & ] & 0 & $\Lambda$ & 0,434 & 0 & 0 \\
\hline [ & R27 & ] & 0 & $\Lambda$ & 0,434 & 0 & 0 \\
\hline
\end{tabular}

Sumber: Penerapan Metode Fuzzy Takagi-Sugeno untuk prediksi Permintaan Barang Produk Mie Instan di Minimarket A. 2015

Metode defuzifikasi pada Takagi-Sugeno menggunakan metode weighted average (WA). Nilai yang sudah dihitung pada proses fungsi implikasi didapatkan $\alpha$ predikat yang tidak nol, yaitu terdapat pada aturan rule [R4], [R5], [R6], [R7], [R8], [R9], [R13], [R14], [R15], [R16], [R17], dan [R18] maka pencarian jumlah pembeliannya ialah :

$$
\begin{aligned}
& (\mathrm{Z} \times \alpha \text {-predikat })_{4}+(\mathrm{Z} \times \mathrm{x} \alpha \text {-predikat })_{5}+(\mathrm{Z} \times \mathrm{x} \text {-predikat })_{6}+(\mathrm{Z} \times \alpha \text { - }
\end{aligned}
$$

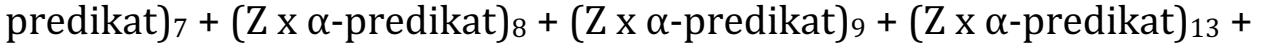

$$
\begin{aligned}
& (\mathrm{Z} \times \alpha \text {-predikat })_{14}+(\mathrm{Z} \times \alpha \text {-predikat })_{15}+(\mathrm{Z} \times \alpha \text {-predikat })_{16}+(\mathrm{Z} \times \alpha \text { - } \\
& \mathrm{Z} \approx \\
& \text { predikat })_{17}+(\mathrm{Z} \times \alpha \text {-predikat })_{18}
\end{aligned}
$$

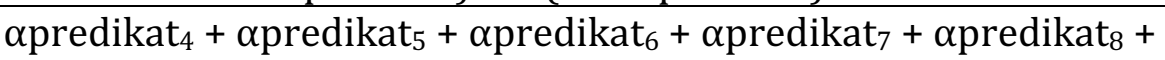

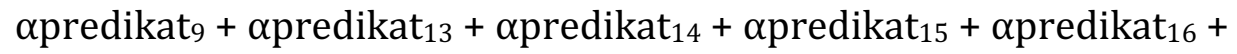

$$
\begin{aligned}
& \approx 84,269 \\
& \text { opredikat }_{17}+\text { apredikat }_{18} \\
& \approx 84
\end{aligned}
$$

Jadi, hasil prediksi jumlah pembelian pada minggu ke 30 ialah 84 bungkus, dibandingkan dengan data real pada minggu ke 30 minimarket melakukan pembelian sebanyak 100 bungkus. 
Proses yang sama dilakukan untuk memprediksi semua data uji, hasil yang didapat akan dibandingkan dengan data real pembelian minimarket, hasilnya sebagai berikut :

Tabel 8 Perbandingan Hasil Prediksi Data Uji

\begin{tabular}{lcllll}
\hline $\begin{array}{c}\text { Minggu } \\
\text { ke }\end{array}$ & Tanggal & Penjualan & $\begin{array}{c}\text { Sisa } \\
\text { stok }\end{array}$ & Pembelian & $\begin{array}{l}\text { Prediksi } \\
\text { Fuzzy T-S }\end{array}$ \\
\hline 21 & $19 / 10 / 2014$ & 202 & 469 & 250 & $-82,895$ \\
22 & $26 / 10 / 2014$ & 206 & 517 & 150 & $-122,692$ \\
23 & $02 / 11 / 2014$ & 304 & 461 & 100 & 141,035 \\
24 & $09 / 11 / 2014$ & 201 & 257 & 200 & 144,597 \\
25 & $16 / 11 / 2014$ & 185 & 256 & 100 & 113,969 \\
26 & $23 / 11 / 2014$ & 153 & 171 & 150 & 118,395 \\
27 & $30 / 11 / 2014$ & 195 & 168 & 150 & 200,049 \\
28 & $07 / 12 / 2014$ & 107 & 123 & 200 & 73,628 \\
29 & $14 / 12 / 2014$ & 113 & 216 & 200 & 4,578 \\
30 & $21 / 12 / 2014$ & 199 & 303 & 100 & 84,269 \\
\hline
\end{tabular}

Sumber : Penerapan Metode Fuzzy Takagi-Sugeno untuk prediksi Permintaan Barang Produk Mie Instan di Minimarket A. 2015

Dari tabel di atas terlihat perbedaan antara jumlah pembelian real minimarket dengan hasil Prediksi Fuzzy Takagi Sugeno. Terdapat beberapa hasil prediksi yang berbeda jauh dengan data real, ini dikarenakan pembelian yang dilakukan oleh minimarket masih bersifat manual(asal), sehingga tidak memperhitungkan berapa jumlah stok yang masih tersedia. Oleh karena itu agar dapat menghitung nilai error, dilakukan perbandingan hasil prediksi dengan pembelian standar (Cumlah penjualan-sisa stok)+stok standar) minimarket, yang dimana stok standar minimarket untuk mie instan $\mathrm{X}$ berjumlah 210 bungkus.

Dari hasil prediksi yang sudah didapat, maka dihitung nilai MAPE (Mean Absolute Percentage Error), dengan rumus sebagai berikut :

$$
\text { MAPE }=\frac{1}{n} \sum_{\mathrm{t}=1}^{\mathrm{n}} \frac{|\mathrm{Yt}-\widehat{\mathrm{Y}}|}{\mathrm{Yt}} \times 100 \%
$$

Berikut tabel perbandingan hasil prediksi dengan pembelian standar minimarket untuk menghitung nilai MAPE yang dilihat dari selisih prediksinya :

Tabel 9 Perbandingan Prediksi

\begin{tabular}{lllll}
\hline $\begin{array}{c}\text { Minggu } \\
\text { ke }\end{array}$ & \multicolumn{1}{c}{$\begin{array}{c}\text { Pembelian } \\
\text { Standar (Yt) }\end{array}$} & $\begin{array}{c}\text { Hasil } \\
\text { Prediksi }\left(\mathbf{Y}^{\wedge} \mathbf{t}\right)\end{array}$ & $\left|\mathbf{Y t}-\mathbf{Y}^{\wedge} \mathbf{t}\right|$ & $\frac{\left|\mathbf{Y t}-\mathbf{Y}^{\wedge} \mathbf{t}\right|}{\mathbf{Y t}}$ \\
\hline 21 & $-57,000$ & $-82,895$ & 25,895 & $-0,454$ \\
22 & $-101,000$ & $-122,692$ & 21,692 & $-0,215$ \\
23 & 53,000 & 141,035 & 88,035 & 1,661 \\
24 & 154,000 & 144,597 & 9,403 & 0,061 \\
25 & 139,000 & 113,969 & 25,031 & 0,180 \\
26 & 192,000 & 118,395 & 73,605 & 0,383 \\
27 & 237,000 & 200,049 & 36,951 & 0,156 \\
28 & 194,000 & 73,628 & 120,372 & 0,620 \\
29 & 107,000 & 4,578 & 102,422 & 0,957
\end{tabular}




\begin{tabular}{|c|c|c|c|c|}
\hline $\begin{array}{c}\text { Minggu } \\
\text { ke }\end{array}$ & $\begin{array}{c}\text { Pembelian } \\
\text { Standar (Yt) }\end{array}$ & $\begin{array}{c}\text { Hasil } \\
\text { Prediksi (Y't) }\end{array}$ & $\left|Y t-Y^{r} t\right|$ & $\frac{\left|\mathbf{Y t}-\mathbf{Y}^{\mathrm{n}} \mathrm{t}\right|}{\mathrm{Yt}}$ \\
\hline 30 & 106,000 & 84,269 & $\begin{array}{c}21,731 \\
\left|\mathbf{Y t}-\mathbf{Y}^{\prime} \mathbf{t}\right| \\
\mathbf{Y t}\end{array}$ & $\begin{array}{l}0,205 \\
3,555\end{array}$ \\
\hline
\end{tabular}

Sumber : Penerapan Metode Fuzzy Takagi-Sugeno untuk prediksi Permintaan Barang Produk Mie Instan di Minimarket A. 2015

$$
\begin{aligned}
\text { MAPE } & =\frac{1}{n} \sum_{t=1}^{n} \frac{|Y t-\hat{Y} t|}{Y t} \times 100 \% \\
& =\left(\frac{1}{10} \times 3,555\right) \times 100 \% \\
& =35,55 \%
\end{aligned}
$$

\section{SIMPULAN}

Dari hasil penelitian dan pengamatan dari sistem yang telah dibuat, maka dapat diperoleh kesimpulan sebagai berikut:

a. Metode fuzzy inference Takagi-Sugeno dapat memprediksi pembelian mie instan,

b. Hasil prediksi permintaan stok mie instan dengan metode fuzzy inference Takagi-Sugeno terdapat selisih error MAPE sebesar 35,55 \%.

\section{DAFTAR PUSTAKA}

[1] Bahroini, Ahmad. "Penerapan Metode Fuzzy Takagi-Sugeno untuk prediksi Permintaan Barang Produk Mie Instan di A Sungai Paring Martapura", Program S-1 Ilmu Komputer, Universitas Lambung Mangkurat, Banjarbaru. 2015

[2] Kusumadewi, S. "Analisis Desain Sistem Fuzzy Menggunakan Tool Box Matlab", Graha Ilmu, Yogyakarta, 2002

[3] Kusumadewi, S. "Aplikasi Logika Fuzzy untuk Pendukung Keputusan", Graha Ilmu, Yogyakarta, 2010

[4] Sutojo, T., Mulyanto, E., \& Suhartono. "Kecerdasan Buatan", Andi Offset, Yogyakarta, 2011

[5] WINA. “Global Demand of Instant Noodles", Report World Instant Noodless, Osaka, 2014.

[6] Yudanto, A. Y., Apriyadi, M., \& Sanjaya, K.. “Optimmalisasi Lampu Lalu Lintas dengan Fuzzy Logic”, ULTIMATICS, Vol. V, No.2, 2013 